Dept. of Food Hygiene,

Animal Health Research Institute, Alexandria, Egypt.

\title{
EVALUATION OF NUTRITIONAL AND HYGIENIC QUALITY OF HERRING FISH AND ITS PRODUCTS
}

(With 5 Tables)

\author{
By \\ MERVAT KAMAL IBRAHIM RAGAB \\ (Received at 4/9/2008) \\ تقييم الجودة الصحية والغذائية لسمك الرنجة ومنتجاتة \\ مرفت كمال ابرا هيم رجب
}

لقد تم جمع 100 عينة من سمك الرنجة (المستورد) المجمدة وكذلك منتجاته وتشمل الرنجه

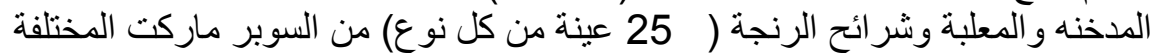

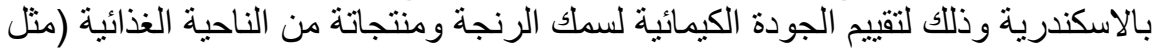
نسبة الدهون الكلية وتركيب الاحماض الدهنية ونسبة البروتين الكلى وكذلك نسبة المعادن

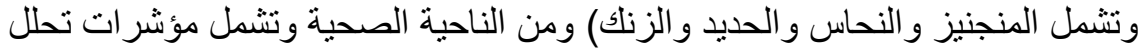

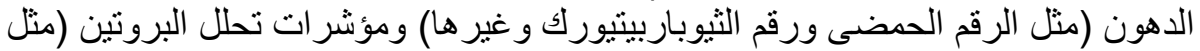

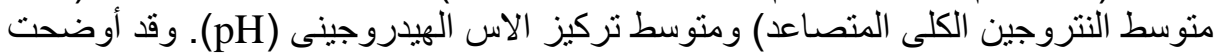

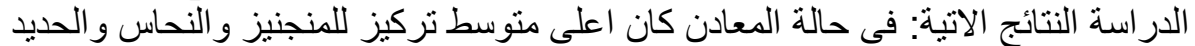

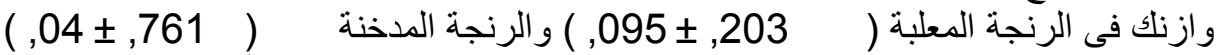

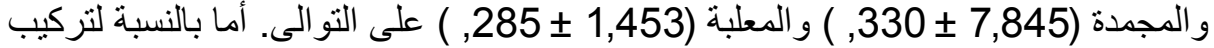

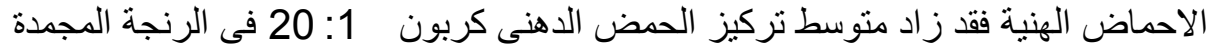

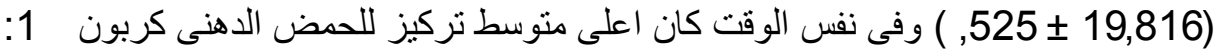
16فى الرنجة المعلبة ( 19,84 1912, 612, ) وفى حالة الحمض الدهنى كربون

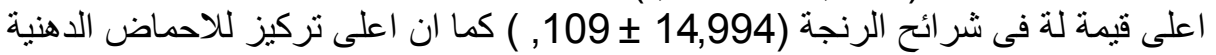

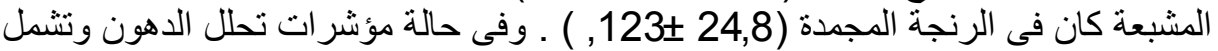
الرقم الحمضى والاحماض الدهنية الحرة ومؤشرات تأكسد الدهون الابتدائية ( (CD) و الثانوية

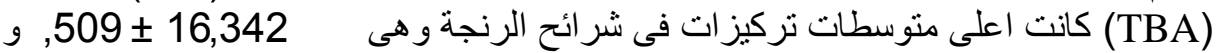

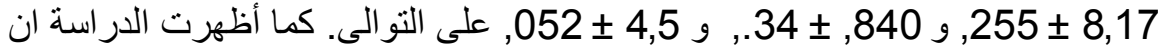

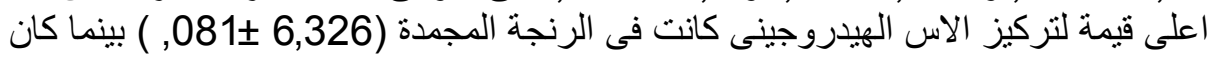
اعلى منوسط تركيز للنيتروجين الكلى المتصاعد فى الرنجة المدخنة ( 29,321 ـ 049, )

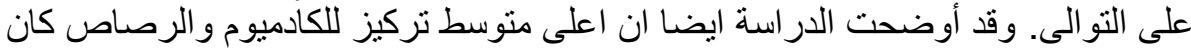

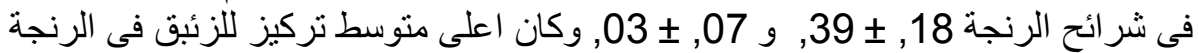

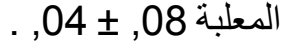




\section{SUMMARY}

Atotal of 100 samples of imported frozen herring fish and its products (smoked, canned and herring fillet, 25 samples of each, were collected from different retail stores in Alexandria governorate to evaluate their chemical quality. The results revealed that fat and protein contents had significantly increased in herring fillet and smoked herring with a mean value of $9.024 \pm 1.764$ and $36 \pm 2.541$. Concerning manganese $(\mathrm{Mn})$ and zinc $(\mathrm{Zn})$, canned herring showed the highest mean concentrations $(0.203 \pm 0.095$ and $1.453 \pm 0.285$, respectively). In case of copper $(\mathrm{Cu})$ and Iron $(\mathrm{Fe})$, smoked and frozen herring had the highest mean values $(0.761 \pm 0.04$ and $7.845 \pm 0.330$, respectively). Regarding fatty acids composition, frozen herring had a significant increase in concentration of Eicosenoic fatty acid with a mean value of $19.816 \pm 0.525$, while canned herring showed the highest mean concentration of palmitic acid (19.084 \pm 0.612$)$. Herring fillet showed the highest value of Linoleic acid (14.994 \pm 0.109$)$. Regarding saturated fatty acids, canned herring had the highest value $(38.074 \pm 0.218)$ while herring fillet showed the highest unsaturated fatty acids (74.626 \pm 2.810$)$. The highest total unsaturated fatty acids was in frozen herring (24.8 \pm 0.123$)$. Concerning fat changes, acid number, free fatty acids, conjugated dienes, thiobarbeturic acid, were highest in herring fillet $(16.342 \pm 0.509,8.17 \pm 0.255,0.840 \pm 0.034$ and $4.5 \pm 0.052$, respectively). In case of acidity $(\mathrm{pH})$ and total volatile nitrogen, the highest $\mathrm{pH}$ value was in frozen herring $(6.3 \pm 0.081)$, while the highest total volatile nitrogen was in smoked herring (29.321 \pm 0.049$)$. Regarding cadmium, lead mercury, the highest mean concentrations of cadmium and lead, were in herring fillet $(0.07 \pm 0.03$ and $0.39 \pm 0.18)$ whereas and the highest concentration of mercury was in canned herring $(0.08 \pm 0.04)$.

Key words: Herring, fatty acids, protein, minerals.

\section{INTRODUCTION}

Fish products elaborated from fatty fish have lately attracted strong interest on fish processing industry and consumers due to their nutritional value, mainly associated to its high content in essential fatty acids, n-3 fatty acids (Aidos., et al., 2003). Herring is a typical pelagic fatty fish with a high content of omega 3 fatty acids such as eicosapentaenoic acid (EPA, C20:5) and docosahexaenoic acid (DHA, 
C22:6) which have positive effect against cardiovascular disease, cancer, etc (Unde land et al., 1998; El-Sharnouby, 1989; Stefánsson et al., 1995; Mindieu et al., 2007). Unfortunately, the development of lipid oxidation often limits the possibilities for storage and processing of this species. This is due to close contact between the highly unsaturated herring lipids and strong catalytic systems (Undeland et al., 1999). The rate of lipid oxidation was monitored by the formation of different oxidised compounds resulting from lipids such as hydroperoxides, aldehydes and fluorescent interaction compounds. (Isabel Medina et al., 2003).

Chemical composition of herring fish can vary widely not only from fish to fish of the same species but also, within an individual fish. Many factors influence the composition of the lipid phase in fish muscle and its deterioration: species of fish, composition of diet, nutritional status, salinity, migrations, genetic factors, season of catch in post mortem handling, time of frozen storage and the prescence of oxygen and light (Ingemanasson et al., 1995).

With respect to nutritional value, it was found that smoking process have no effect on fatty acid of fresh or raw fish (Bhujyan et al.,1986).

It was reported that the total lipid content of fish was slightly decreased after salting and smoking processes (Abdel Nabey, 1995; Ikem and Eagiebor, 2005).

The fat content of baltic herring, mackerel and salmon from Norway has been determined .The fat content was $7 \%, 11.6 \%$ and $13.2 \%$, respectively. Both fat extracted from mackerel and salmon contained much more of PUFA $S$ in comparison to that extracted from herring. PUFA content in herring fat was $15 \%$, whereas in mackerel and salmon were $29 \%$ and $25 \%$, respectively. PUFA represented mostly of omega 3 family (Balass et al., 2001) The lipid content of the muscle tissue of fishes sampled amounted to $8.7 \%$ in Baltic herring. The qualitative composition of the fatty acids in the fish lipids was the same but it varied quantitatively. Unsaturated fatty acids constituted $66.86 \%$ in the herring lipids, C $20: 5$ and C $22: 5$, C $22: 6$. constituted 16.61, 28.48 , and $16.49 \%$ of all fatty acids, respectively (Szczepanik and Stodolnik, 2003). There was a difference in fatty acid pattern in raw, frozen, Smoked salmon. The content of c20: $5 \mathrm{n} 3$ and c22:6 n3 ranged from 4.2 to 13.3 and the $n 3$ series of polyunsaturated fatty acids (PUFA) were $32.4 \%$ of total fatty acids in marine fish (Marta et al., 2004). It was reported that smoked salmon had total lipid contents higher in c18:0, c18:2 fatty acid, Also in sigma monoenoic fatty acids, however, C16: 
1polyunaturated $\mathrm{n} 3$ fatty acid of health benefits as c20:5, c22:5, c22:6, revealed significant decreases in smoked than frozen. Mohammed, (2004) reported that fatty acids composition of salted herring products was typical for herring, the most abundant fatty acids being oleic (c18 :1n-9), palmitic (16:0) monounsaturated fatty acids constituted the main group with a proportion of $>50 \%$ of all fatty acids. EPA, 20: 5n_3) and DHA, 22: $6 \mathrm{n} \_3$ comprised $12 \%$ of all fatty acids (Minh Dieu, et al., 2007)

Moreover several studies were carried out on hygienic quality of smoked herring. The free fatty acids contents of fish samples were very high indicating microbial spoilage activity. Fat activity begins to be noticeable to the palate when the free fatty acid values calculated as oleic acid is about 0,5 to $1,5 \%$. (Pearson, 1978). The increase in T.B.A value was related to the transformation of some unsaturated fatty acids especially those at surface to peroxides, conjugated dienes (CD) as resulted exposuer to atmosperic oxygen, appplied temperature during smoking process which may accelerate oxidation and thereby lipid breakdown, another factor is salt which can penetrates into the muscle during dry saltingor brining. (Salama and Khlafalla, 1993; Marta, 2004).

The total volatile nitrogen content (T.V.N.) of lanhouin (fermented fish product) samples were very high for both species of fish (cassava fish and king fish) ranged from $29.5 \mathrm{mg} \mathrm{N} / 100 \mathrm{gm}$ of sample to $38.98 \mathrm{mg} \mathrm{N} / 100 \mathrm{gm}$ from one species to another with an average of 29.45 and $37.45 \mathrm{mgN} / 100 \mathrm{gm}$ for cassava fish and king fish, respectively (Anihouvi, et al., 2006).

Kewaiey (2001) showed that smoked herring fish had mean $\mathrm{pH}$ value of 6.15 and differ significantly between salted and smoked fish, T.V.B.N. was $47.36 \mathrm{mgN} / 100 \mathrm{gm}$ was highly significant between salted, smoked fish at $\mathrm{P}<0.01$, mean F.F.A.=9.93 differ significantly at $\mathrm{p}<0.05$ between salted and smoked fish.

Shaban, and Abo Zeed (2004) reported that the smoking process of Lizard fish and the $\mathrm{pH}$ value was decreased while the amino nitrogen was increased.

Since herring fish is important to human health due to its high content of omega 3 fatty acids, on the other hand herring fish is more susceptible to deterioration during storage and processing than other types of fish, therefore the purpose of this work is to give an idea about the nutritional and hygienic quality of herring fish and its products. 


\section{MATERIALS and METHODS}

A total of 100 samples of imported frozen herring fish (Clupea harengus) and its products, smoked, canned and herring fillet (25 for each) were selected randomly from Alexandria retail stores. Samples were transported in an insulated ice box to the laboratory and analyzed for chemical quality parameters.

1- Determination of chemical quality parameters

1-1- Nutritional quality parameters

1-1-1- Fat content: It was determined according to standard method obtained by AOAC (1970).

1-1-2- Fatty acids composition: The methyl esters of extracted fish lipids were prepared according to Radwan, (1978) and fatty acids composition was determined by using Gas Liquid Chromatography (GLC). (Radwan, 1978).

1-1-3- Protein content: It was determined according to standard method obtained by AOAC (1970).

1-1-4- Mineral composition ( $\mathrm{Mn}, \mathrm{Cu}, \mathrm{Fe}, \mathrm{Zn}$,):

The principle of the minerals determination involved the production of acidic solution of the inorganic elements, after removing interferring materials by chelation solvent using ammonium pyrrolidine di-thio carbamate (APDC) and isobutyl methyl ketone (MIBK). After that minerals concentrations were determined by using flame atomic absorption spectrophotometer at wave length's specific to each element (Richard, 1986).

1-2- Hygienic quality parameters:

1-2-1-Fat quality indicators:

1-2-1-1-Acid number:

Acid number is defined as the number of milligrams of potassium hydroxide required to neutralize the free acid in $1 \mathrm{gm}$ of the sample. It was determined according to Pearson (1970).

1-2-1-2- Free fatty acids: it was estimated according to Pearson (1970)

1-2-1-3- Conjugated dienes: it can be determined using ultraviolet (UV) - visible spectrophotometer. (Sanitago et al., 1997).

1-2-1-4- Thiobarbeturic acid reactive substances (TBAR): It was determined using cold extraction method according to Li, et al. (2001). 1-2-2- hydrogen ion concentration $(\mathrm{pH})$ : The $\mathrm{pH}$ of fish muscle was determined according to AOAC (1980).

1-2-3- Protein quality indicator: Total volatile nitrogen (TVN) was determined by macrokejldhal Method (Malle and Pourmeyrol, 1998). 
1-2-4- Contaminant levels $(\mathrm{Cd}, \mathrm{Pb}, \mathrm{Hg})$ : Cadmium and lead were determined by Hydrochloric-nitric $\left(\mathrm{HCl}-\mathrm{HNO}_{3}\right)$ acid leaching method using flame atomic absorption spectrophotometer (Richard, 1986). The principle of mercury $(\mathrm{Hg})$ determination method depends on the conversion of all the $\mathrm{Hg}$ present in the sample into the inorganic form by wet oxidation and it's reduction to the metallic state. Then, the realse of $\mathrm{Hg}$ from the solution as vapour using a stream of air followed by it's determination by flameless atomic absorption spectrophotometer (APHA/AWWA1992).

\section{RESULTS}

Table 1: Chemical composition (mean \pm standard error) of herring fish and its products.

\begin{tabular}{|c|c|c|c|c|c|c|}
\hline \multirow{3}{*}{$\begin{array}{c}\text { Herring } \\
\text { fish } \\
\text { and its } \\
\text { products }\end{array}$} & Total lipids (\%) & Total protein & \multicolumn{4}{|c|}{ Mineral composition(p.p.m.) } \\
\hline & \multirow[t]{2}{*}{ Mean \pm S.E } & \multirow[t]{2}{*}{ Mean \pm S.E } & \multicolumn{4}{|c|}{ Mean \pm S.E } \\
\hline & & & $\begin{array}{c}\text { Mn } \\
\text { magnesium }\end{array}$ & $\begin{array}{c}\mathrm{Cu} \\
\text { copper }\end{array}$ & $\begin{array}{c}\mathrm{Fe} \\
\text { iron }\end{array}$ & $\begin{array}{c}\mathrm{Zn} \\
\mathrm{Zinc}\end{array}$ \\
\hline Frozen & $7.229 * * \pm 0.138$ & $18 * * 1.091 *$ & $0.051 \pm 0.003$ & $0.746 \pm 0.058$ & $7.845^{* * \pm 0.330}$ & $0.312 * \pm 0.038$ \\
\hline Smoked & $8.126^{* *} \pm 0.768$ & $36^{*} \pm 2.541$ & $0.041 \pm 0.006$ & $0.761 \pm 0.040$ & $1.891^{* * \pm 0.472}$ & $0.609 * \pm 0.194$ \\
\hline Canned & $2.303 * * \pm 0.539$ & $23 * * \pm 1.332$ & $0.203 \pm 0.095$ & $0.687 \pm 0.017$ & $5.880 * \pm 0.527$ & $1.453 * \pm 0.285$ \\
\hline Fillet & $9.024 * * \pm 1.764$ & $35^{*} \pm 2.160$ & $0.151 \pm 0.049$ & $0.698 \pm 0.022$ & $4.899 * \pm 0.450$ & $0.720 * \pm 0.053$ \\
\hline
\end{tabular}

* Significant at $\mathrm{P} \leq 0 ., 05$

** Highly significant at $\mathrm{P} \leq 0,05$ 
Table 2: Fatty acids composition (mean \pm SE) of herring fish and its products in percent. $(\mathrm{n}=25)$

\begin{tabular}{|c|c|c|c|c|}
\hline Fatty acids & Frozen & Smoked & Canned & Herring fillet \\
\hline Capric $\left(\left(\mathrm{C}_{10: 0}\right)\right.$ & $0.963 * * \pm 0.113$ & $0.424 \pm 0.267$ & $1.099 \pm 0.152$ &.., $126 \pm 0.060$ \\
\hline Lauric $\left(\mathrm{C}_{12: 0}\right)$ & $0.147 * \pm 0.017$ & $0.288 \pm 0.032$ & $0.787 \pm 0.112$ & $0.206 \pm 0.049 * *$ \\
\hline Myristic $\left(\mathrm{C}_{14: 0}\right)$ & $8.959 * * \pm 0.613$ & $9.986^{* *} \pm 0.264$ & $5.733 * \pm 0.542$ & $1.316 \pm 0.134$ \\
\hline Pentadecanoic $\left(\mathrm{C}_{15: 0}\right)$ & $0.499 * \pm 0.158 *$ & $.314 \pm 0.058$ & $1.423 * * \pm 0.080$ & $0.321 \pm 0.012$ \\
\hline Palmitic $\left(\mathrm{C}_{16: 0}\right)$ & $19.049 * * \pm ., 653$ & $19.069 * * \pm 0.521$ & $19.084 * * \pm 0.612$ & $15.130 * * \pm 0.324$ \\
\hline Palmitoleic $\left(\mathrm{C}_{16: 1}\right)$ & $6.155^{* * \pm ., 541}$ & $14.287 * * \pm 0.313$ & $3.184 * \pm 0.418$ & $1.152 \pm 0.154$ \\
\hline Heptadecanoic $\left(\mathrm{C}_{17: 0}\right)$ & $0.733 * \pm 0.080$ & $0.772 * \pm 0.213$ & $0.98 * * 7 \pm 0.198$ & $0.502 \pm 0.039$ \\
\hline Stearic $\left(\mathrm{C}_{18: 0}\right)$ & $0.998 * \pm 0.112$ & $3.103 * * \pm 0.674$ & $5.875^{*} \pm 1.432$ & $5.963 \pm 0.040^{* * *} *$ \\
\hline Oleic $\left(\mathrm{C}_{18: 1}\right)$ & $18.099 * * \pm 0.417$ & $10.453 * * \pm 0.176$ & $14.745^{* * \pm 1.098}$ & $18.102 * * \pm 0.650$ \\
\hline Lenoleic $\left(\mathrm{C}_{18: 2}\right)$ & $1.186 \pm 0.160$ & $2.307 * * \pm 0.234$ & $7.105^{*} \pm 1.134$ & $14.994 * * \pm 0.109$ \\
\hline Lenolenic $\left(\mathrm{C}_{18: 3}\right)$ & $1.661 \pm 0.164$ & $2.527 * * \pm 0.146$ & $2.003 \pm 0.132$ & $7.317 \pm 0.504$ \\
\hline Arachidic $\left(\mathrm{C}_{20: 0}\right)$ & $1.483 \pm 0.123$ & $2.121 * * \pm 0.146$ & $3.005 \pm 0.057$ & $0.699 \pm 0.130$ \\
\hline Eicosenoic $\left(\mathrm{C}_{20: 1}\right)$ & $19.816^{* *} \pm 0.525$ & $18.254 * * \pm 1.765$ & $18.23 * \pm 0.769$ & $15.872 * * \pm 1.800$ \\
\hline EPA $\left(C_{20: 5}\right) n-3$ & $9.40 * * \pm 0.660$ & $8.60 * * \pm 0.360$ & $8.3^{* *} . \pm .0568$ & $8.800 \pm 1.543$ \\
\hline$\left(C_{22: 5}\right) n-3$ & $0.952 * \pm 0.128$ & $0.545 \pm 0.013$ & $0.40 \pm 0.021$ & $0.6 \pm 0.141$ \\
\hline DHA $\left(C_{22: 6}\right) n-3$ & $9.90 * * \pm 0.230$ & $6.95 * * \pm 0.159$ & $8.04 * * \pm 0.823$ & $8.90 \pm 0.323$ \\
\hline Saturated fatty acids & $26.831 * * \pm 1.651$ & $30.077 * * \pm 0.713$ & $38.074 * . * \pm 0.218$ & $25.37 * * 4 \pm 1.239$ \\
\hline Unsaturated fatty acids & $73.169 * * \pm 2.872$ & $69.921 * * \pm 0.845$ & $61.926 * * \pm 0.714$ & $74.626 * * 2.810$ \\
\hline Total n-3 unsaturated fatty acids & $24.8 * * \pm 1.123$ & $20.4 * * \pm 0.768$ & $20 * * \pm 0.840$ & $23.6 * * \pm 0.304$ \\
\hline
\end{tabular}

** Highly significant at $\mathrm{P} \leq 0.05$

* significant at $\mathrm{P} \leq 0.05$

Table 3: Fat quality indicators (mean \pm SE) in herring fish and its products

\begin{tabular}{|c|c|c|c|c|}
\hline Samples & $\begin{array}{l}\text { Acid number } \\
{[\mathrm{mg} \mathrm{KOH} / \mathrm{g} \text { of }} \\
\text { fat }]\end{array}$ & $\begin{array}{l}\text { Free fatty } \\
\text { acids }(\mathrm{ml} / \mathrm{gm})\end{array}$ & $\begin{array}{l}\text { Conjugated } \\
\text { dienes } \\
(\mathrm{n} \mathrm{mole} / \mathrm{mg}) \\
\end{array}$ & $\begin{array}{c}\text { TBARS } \\
\text { [mg malonaldehyde/ } \\
\text { kg of sample] }\end{array}$ \\
\hline Frozen & $5.371 * * \pm 0.315$ & $2.686^{* * \pm 0.158}$ & $0.46 * 0 \pm 0.037$ & $3.624 * \pm 0.151$ \\
\hline Smoked & $8.785^{* *} \pm 0.230$ & $4.393^{* *} \pm 0.115$ & $0.63 * \pm 0.022$ & $4.378 * \pm 0.076$ \\
\hline Canned & $1.167 * * \pm 0.102$ & $0.584 * * \pm 0.051$ & $0.15 * \pm 0.037$ & $2.391 * \pm 0.176$ \\
\hline Fillet & $16.342 * * \pm 0.509$ & $8.17 * * \pm 0.255$ & $0.84 * \pm 0.034$ & $4.500 * \pm 0.052$ \\
\hline
\end{tabular}

* Significant at $\mathrm{P} \leq 0.05$

** Highly significant $\mathrm{P} \leq 0.5$ 
Table 4: Hydrogen ion concentration $(\mathrm{pH})$ and total volatile nitrogen content (T.V.N.) of herring fish and its products

\begin{tabular}{|l|c|c|}
\hline Herring fish and its products & $\begin{array}{c}\text { Hydrogen ion } \\
\text { conc. }(\text { PH })\end{array}$ & $\begin{array}{c}\text { Totalvolatile nitrogen } \\
\text { (T.V.N.) }\end{array}$ \\
\cline { 2 - 3 } & Mean \pm S.D & Mean \pm S.D \\
\hline Frozen & $6.326 \pm 0.081$ & $26.432^{*} \pm 0.032$ \\
\hline Smoked & $6.157 \pm 0.035$ & $29.32^{*} 1 \pm 0.049$ \\
\hline Canned & $6.077 \pm 0.046$ & $28.43^{*} \pm 0.098$ \\
\hline Fillet & $6.253 \pm 0.041$ & $27 . *^{*} \pm 0.035$ \\
\hline
\end{tabular}

* Significant at $\mathrm{P} \leq 0.001$

Table 5: Cadmium, lead and mercury levels (p.p.m) in herring fish and its products.

\begin{tabular}{|c|c|c|c|}
\hline \multirow{2}{*}{ Samples } & \multicolumn{3}{|c|}{ Contaminant levels(p.p.m) } \\
\cline { 2 - 4 } & Cadmium & Lead & mercury \\
\cline { 2 - 4 } & Mean \pm S.D & Mean \pm S.D & Mean \pm S.D \\
\hline Frozen & $0.03 \pm 0.01$ & $0,16 \pm 0.05$ & $0.074 \pm 0.04$ \\
\hline Smoked & $0.02 \pm 0.01$ &, $15 \pm 0.08$ & $0.05 \pm 0.02$ \\
\hline Canned & $0.04 \pm 0.01 *$ &, $18 \pm 0.04$ & $0.08 \pm 0.04$ \\
\hline Fillet & $0.07 \pm 0 . ., 03$ &, $39 \pm 0.18$ & $0.06 \pm 0.03$ \\
\hline
\end{tabular}

\section{DISCUSSION}

Chemical composition of herring fish and its products were recorded in Table (1). Results showed that the highest percent of fat was found in herring fillet $(9.024 \%)$ while the lowest was in canned herring $(2.303 \%)$. There was a highly significant difference in percent of fat between herring fish and its products at $\mathrm{p} \leq 0.05$. The increase in fat content of herring fish products was due to the decrease in moisture content in smoke cured product. Moreover, the highest mean value of protein content $(36 \%)$ was in smoked herring fish, while the lowest $(18 \%)$ was in frozen herring with a highly significant difference between them at $\mathrm{p} \leq 0.05$. This result was in agreement with Shaban and 
Abo Zeed, (2004) who studied the effect of fish smoking process on lizard fish and Salama and Khalafalla (1993) in eels fish.

Concerning mineral composition, the mean values of manganese $(\mathrm{Mn})$, ranged from 0.041 p.p.m in smoked herring to 0.203 p.p.m in canned herring. In case of copper $(\mathrm{Cu})$, smoked herring showed the highest mean concentration (0.761p.p.m) while canned herring had the lowest (0.687 p.p.m). Regarding Fe and $\mathrm{Zn}$, the highest levels (7.845 p.p.pm and 1.453 p.p.m, respectively) were in frozen and canned herring. While the lowest were 1.891 p.p.m and 0.312 p.p.m in smoked and frozen herring, respectively (Table 1). The obtained results lies within the Egyptian standard limits. (Egyptian Standard Regulation, 1993).

It was found that processing of herring fish does not have a major impact on the macrocontent of bony fish. Dehydration potenially can have the biggest effect, by removing water. Brining and smoking can result in a partial removal of moisture, with consequent increases in the proportions of macronutrients. Lack of care (resulting in excessive temperatures) in smoking can cause loss of lipids from herring (Holland, et al.,1993; Aidos, et al., 2003).

Fatty acids composition of herring fish and its products were recorded in Table (2). The mean values of saturated fatty acids were $26.831 \%, 30.077 \%, 38.074 \%$ and $25.374 \%$ in frozen, smoked, canned and fillet, respectively. At the same time, the unsaturated fatty acids showed mean values of 73.169, 69.921, 61.926 and $74.626 \%$ in frozen, smoked, canned and fillet, respectively. The highest significant percent of Palmitic $\left(\mathrm{C}_{16: 0}\right)$ was found in canned herring $(19.084 \%)$, and the lowest was in herring fillet $(15.130 \%)$, while the highest significant percent of ecicosapentaenoic (EPA) $\left(\mathrm{C}_{20: 5}\right) \mathrm{n} 3, \quad\left(\mathrm{C}_{22: 5}\right) \mathrm{n}-3$, docosahexaenoic (DHA) $\left(\mathrm{C}_{22: 6}\right) \mathrm{n}-3$ were in frozen herring fish $(9.4 \%$, $0.952 \%, 9.9 \%)$, respectively. The increase in saturated fatty acids after processing may be attributed to the transforrmation (saturation) of some of the monounsaturated fatty acids and / or polyunsaturated to saturated fatty acids results from direct feeding on the phytoplankton and or feeding on fish that had already fed on phytoplankton. Nearly similar observations were reported by Gopakumar and Nair (1972), Marta., et al. (2004), Mohammed, (2004) and Aro. et al., (1983).

The percentage of polyunsaturated fatty acids decreased as a result of salting and smoking processes (Steffens, 1997).

Table (3) illustrated the fat quality indicators in herring fish and its products. Results of lipid hydrolysis showed that the highest mean 
values of acid number and free fatty acids $(16.342 \mathrm{mgkoH} / \mathrm{gm}$ of fat, $8.17 \mathrm{ml} / \mathrm{gm}$ ) were in herring fillet while the lowest were in canned herring $(1.167 \mathrm{mg} / \mathrm{gm}, 0.584 \mathrm{ml} / \mathrm{gm})$ with a high significant difference between them. Concerning, lipid oxidation changes (CD, TBA), herring fillet had the highest value $(0.84 \mathrm{nmole} / \mathrm{mg}, 4.5 \mathrm{mg} / \mathrm{kg})$, while the the lowest was in canned herring $(0.15 \mathrm{n} \mathrm{mole} / \mathrm{mg}, 2.391 \mathrm{mg} / \mathrm{kg})$ with a highly significant difference between mean values of $\mathrm{CD}$ in herring fish and its products at $\mathrm{p} \leq 0.05$.

It was reported that the TBARS of smoked fish products locally produced in Alexandria, was ranged from 2.12 to $2.95 \mathrm{MDA} / \mathrm{Kgm}$ flesh sample with a mean value of $2.51 \mathrm{MDA} / \mathrm{kg}$ flesh sample, (Saber et al., 1992) and higher results were recorded by Emara (2000) after 6 monthes of storage of hot smoked fish.

Hydrogen ion concentration $(\mathrm{pH})$ and total volatile nitrogen content (TVN) of herring fish and its products were recorded in Table (4). The highest level of $\mathrm{pH}$ was found in frozen herring (6.326) followed by herring fillet $(6,253)$, smoked $(6,157)$ and canned $(6.077)$. The reduction in $\mathrm{pH}$ value in herring fish products in our results was due to the organic acid resulted from the smoke content. Similar results were recorded by Daoud and Abdelaziz (1996), Shaban and Abozeed (2004) and Anihouvi, et al. (2006).

In case of total volatile nitrogen content, the highest level $(29.321 \mathrm{mg} / 100 \mathrm{gm})$ was in smoked herring while the lowest $(26.432 \mathrm{mg} / 100 \mathrm{gm})$ was found in frozen herring, with a significant difference between them. According to Connel, (1990) who stated that for good quality, no greater than 100-200mg TVN nitrogen/100gm for a variety of salted, dried fish, herring fish and its products examined in the present study are of good quality. Nearly similar observations were obtained by Stefansson et al., (1995); El-kewaiey, (2001), and Shaban and Abo zeed, (2004).

Mean concentrations (p.p.m.) of cadmium $(\mathrm{Cd})$, lead $(\mathrm{Pb})$, mercury $(\mathrm{Hg})$ in herring fish and its products were presented in Table (5). It was found that the mean values of cadmium, lead, mercury in all the examined samples were within the permissible limits obtained by Egyptian Standard Regulation (1993).

In conclusion, the present study indicated that imported frozen herring fish marketed in Alexandria are of good source of nutritional value. Moreover, the hygienic quality examination revealed that processing and smoking of frozen herring fish increase the susceptibility of lipid oxidation and hence increase the level of fat quality indicators. 
At the same time, the examined herring fish products were of good keeping quality from the point of view of contaminanat levels, $\mathrm{PH}$ and protein quality indicators (TVN).

\section{REFERENCES}

Association of Official Analytical Chemists (A.O.A.C.) (1970): Official methods of analysis $11^{\text {th }}$ ed., Washington, DC.

Association of Official Analytical Chemists (A.O.A.C.) (1980): Official methods of analysis, $13^{\text {th }}$ ed. AOAC, Arlinoblon, V.A.

APHA/AWWA (1992): Standard Methods for Examination of Water and Wastewater, $18^{\text {th }}$ ed. Joint of APHA/AWWA, Washington DC. Anihouvi, V.B.; Ayernor, G.S.; Hounhouigan, J.D. and Esakyi Dawson (2006): Quality characteristic of Lanhouin: A traditionally processed fermented fish product in the republic of Benin. African journal of Food, Agriculture, Nutrition and Development, Vol. 6., (1): 1-8.

Aidos, I.; Schelvis-Smit, R.; Veldman, M.; Luten, J.B.; Van der Padt, A. and Boom, R.M. (2003): Chemical and sensory evaluation of crude oil extracted from herring byproducts from different processing operations. : J Agric Food Chem. Mar 26; 51(7): 1897-903.

Abdel- Nabey, A.A. (1995): Oxidative and hydrolytic change in lipids of hake after smoking. Alex. Sci. Exch. 16: 1-

Aro, T.; Brede, C.; Manninen, P. and Kallio, H. (1983): Determination of semivolatile compounds in Baltic herring (Clupea harengus membras) by supercritical fluid extraction-supercritical fluid chromatography-gas chromatography-mass spectrometry.: Nahrung.; 27(5): 513-8

Balass, J.; Pawlicka, M.; Jacorzynski, B.; Filipe, k.A.; Domina, P.; Mielniczuk, E. and Daniewski, M. (2001): The fat and fatty acid content in selected sea fish. Rocz Panstw Zakl Hig., 52(4): 277-84.

Bhuiyan, A.K.; M.A.; Ratnayake, W.M.N. and Ackman, R.G. (1986): Stability of lipids and polyunsaturated fatty acids during smoking of Atlantic mackerel (Scomber scombrus) J. Am. Oil Chem. Soc., 63 (3): 324-328.

Connel, J.J. (1990): Control of fish quality. $3^{\text {rd }}$ Ed., Black well Scientific publications, Oxford, pp.85-88, 97-103. 
Daoud Jehan, R. and Abdel-Azziz, A.T. (1996): Sensory, bacterial, parasitic and chemical evaluation of smoked fishes (herring) in El- Sharkia governorate. Egypt. J. Agric. Res., 74(4): 10471055.

Emara, Hoda, H. (2000): Chemical and technological studies on fish and fish products: the hot smoke curing of karmout and bayad: Acomparative study. M. Sci. (food science and technology), Fac. Of Agric., Alex. Univ., Egypt.

Egyptian Standard Regulation (1993): Maximum levels for heavy metal contaminanats in foods 1993, 2360.

Elsharnouby, Samira, A. (1989): Chemical and technological studies on fish. (role of enzymes in determining the quality of salted and cured fish. ph. D. Thesis, Fac. Agric. Alex. Univ.

El-kewaiey, I.A. (2001): Quality assessment of some locally manufactured and retailed meat and fish products. Thesis of doctor in food hygiene in Faculty of Veterinary Medicine. Kafr El-sheik, Tanta University .

Gopakumar, K. and Nair, M.R. (1972): Fatty acid composition of eight species of Indian marine fish. J. Sci. Food. Agric. (23): 493496.

Holland, R.M.; Brown, J. and Buss, D.H. (1993): Fish and shell fish products, the third supplementto McCance, Widdowsons, the composition of foods $\left(5^{\text {th }} \mathrm{ed}\right), \mathrm{HMSO}$, London.

Isabel Medina, José, Ma.; Jesús G. and Manuel, P. (2003): Natural antioxidants for preserving quality of fatty fish products. Electron. J. Environ. Agric. Food Chem 2 (1), issn, 1579-4377 (pages 227-229).

Ikem, A. and Eagiebor, N.O. (2005): Assessment of trace elements in canned fishes (mackerel, tuna, salmon, sardines and herrings) marketed in Georgia and Alabama. Journal of Food Composition and Analysis. 18(8): 771-787.

Ingemanasson, T.; Kaufmann, P. and Ekstrand, B.O. (1995): Multivariate evaluation of lipid hydrolysis and oxidation data from light and dark muscle of frozen stored rainbow trout (Oncorhynchus mykiss). J. Agric. Food Chem. 43 (8) 20462048.

Li, C.T.; Wick, M. and Marriott, N.G. (2001): Evaluation of lipid oxidation in animal fat. Bull. Ohio state University, Research and Reviews: Meat Special circular 172: 99 
Marta, D.; Fabiola, C.; Laura, C. and Ricardo, S. (2004): Changes in Quality of vacuum-packed cold smoked salmon (Salmo salar) as a function of storage temperature. Food Chem. 87(4)543548.

Malle and Poumeryrol (1998): Anew chemical Criterion for the quality control of fish: TMA/TVBN (\%). J. Food. Prot. 52(6): 419423.

Minh Dieu Huynh, A; David, D.; Kitts, A.; Chun Hu, A.; Andrew W. Trites (2007): Comparison of fatty acid profiles of spawning and non-spawning Pacifiherring, Clupea harengus pallasic. Comparative Biochemistry and Physiology, Part B 146 (2007) 504.

Mohammed, A.T. (2004): Lipid quality, fatty acids composition and cholesterol content of frozen and smoked atlantic salmon (Salmo Salar) ISSN110-2047. Alex. J. Vet. Science. 21., 2,: 563-573.

Pearson, D. (1970): The chemical analysis of foods. Sixth edition. Printed in Great Britain by T \& A Coustable Ltd Edinburgh.

Pearson, D. (1978): Laboratory techniques in food analysis, London, Boston, Butter worth, Co. Ltd.1978, 51-75.

Radwan, S.S. (1978): Copling of two dimention thin layer chromatography with gas chromatography for quantitative analysis of lipid classes constitiuent fatty acids, journal of chromatographic science, 16: 538.

Richard, F. (1986): Determination of trace elements in food by $\mathrm{HCl}-$ $\mathrm{HNO}_{3}$ leaching and flame atomic absorption spectrophotometry. J AOAC 69(5): 868-871.

Saber, N.M.; Nahed M. El- shemi and kotit, S.M. (1992): Quality attributed of some smoked fish products locally produced in Alexandria. J. Agric. Sci., Mansoura Uni., 17(4): 838-846.

Salama, N.A. and Khalafalla, G.M. (1993): Chemical, bacteriological and sensory changes in eel fish (Anguilla vulgaris) during smoking and storage. Archiv fur lebensmittelhygine 44(1): 6-9. C.F. (F.S.T.A); 25(5), 5R18, 1993.

Steffens, W. (1997): Effect of variation in essential fatty acids in fish feeds on nutritive value of fresh water fish for humans. Aquaculture 151(1-4) 97-101.

Stefánsson, G.; Nielsen, H.H. and Guðmundsdóttir, G. (1995): Ripening of Spice-Salted Herring. TemaNord 1995: 613, Nordic Council of Ministers, Copenhagen 
Santiago, P.; Aubourg, Carmen, G. and Jose, M. (1997): Quality assesment of sardine during storage by measurement of fluorescent compounds. European Food Research and Technology. 62(2): 295-298.

Shaban, A.N. and Abo-zeed, A.N. (2004): Lizard Fish preservation by hot smoking, freezing and canning, A comparative study. Thesis of master degree in food Science, Technology, Faculty of Agriculture, Alexandria, University.

Szczepanik, G., and Stodolnik, L. (2003): The effect of the composition of fatty acids of Baltic fishes and frozen storage process on the antioxidant activity of aqueous extracts of rosemary and sage, as well as BHA and Endox. Acta Ichthyol. Piscat. 33 (1): $57-$ 74.

Undeland, I.; Ekstrand, B.; Hall, G. and Lingnert, H. (1998): Lipid oxidation in minced herring (Clupea harengus) during frozen storage: Influence of washing and pre-cooking. J. Agric. Food Chem., 46, 2319-2328.

Undeland, I.; Ekstrand, B.; Hall, G. and Lingnert, H. (1999): Lipid oxidation in fillets of herring (Clupea harengus) during frozen storage. Influence of pre-freezing storage. J. Agric. Food Chem. 47, 2075-2081. 